\title{
Infections in Cirrhosis
}

\section{Sirina Ekpanyapong, MD}

K. Rajender Reddy, MD*

\author{
Address \\ *Division of Gastroenterology and Hepatology, University of Pennsylvania, 2 \\ Dulles, 3400 Spruce Street, HUP, Philadelphia, PA, 19104, USA \\ Email: rajender.reddy@uphs.upenn.edu
}

Published online: 12 April 2019

(C) Springer Science+Business Media, LLC, part of Springer Nature 2019

This article is part of the Topical Collection on Liver

Keywords Cirrhosis - Spontaneous bacterial peritonitis - Bacterial translocation - Multidrug-resistant . Acute-on-chronic liver failure $\cdot$ Vaccination

\begin{abstract}
Purpose of review Patients with cirrhosis are at high risk of developing serious infections. Bacterial infections remain the most common cause of morbidity and mortality in these patients. This review is focused on the prevalence of infections in those with cirrhosis, including multidrug-resistant (MDR) pathogens, pathogenesis of infection-related acuteon-chronic liver failure (ACLF), current treatment recommendations, and prophylactic strategies in patients with cirrhosis.

Recent findings Recent epidemiological studies have noted an emerging prevalence of MDR bacterial infections and associated with poor prognosis, and a high rate of treatment failure and mortality. Therefore, new recommendations on empirical antibiotic use based on epidemiological data have been developed in order to improve outcomes.

Summary Spontaneous bacterial peritonitis (SBP) and urinary tract infection (UTI) are the most frequent infections followed by pneumonia, cellulitis, and bacteremia, while pneumonia carries the highest risk of mortality. The incidence of MDR bacterial infections has been increasing, especially in healthcare-associated settings. Second infections that develop during hospitalization, multiple organ failures, and high MELD score are associated with poor survival. Preventive measures, early diagnosis, and adequate treatment of infections are essential key concepts in minimizing morbidity and mortality in patients with cirrhosis.
\end{abstract}

\section{Introduction}

Infections, predominantly bacterial in nature, are not uncommon in patients with cirrhosis and these are associated with high morbidity and mortality [1]. In these patients, infections are a consequence of multiple pathophysiological mechanisms such as gut dysbiosis, increased bacterial translocation, 
portosystemic shunting, cirrhosis-associated immune dysfunction (CAID), liver dysfunction, and genetic factors $[2,3]$. The most frequent infections are spontaneous bacterial peritonitis (SBP) and urinary tract infection (UTI) while pneumonia, cellulitis, and bacteremia are not uncommon [4]. Communityacquired bacterial infections account for about 30\% of all infections followed by healthcare acquired in approximately $30 \%$ and nosocomial infections in $35-40 \%[5,6]$. Recent epidemiological data has shown that the incidence of multidrug-resistant (MDR) bacteria is increasing, especially in healthcare-associated settings [6, 7]. MDR bacteriaassociated infections have the worst prognosis and are associated with higher rates of treatment failure, septic shock, and high mortality [4-6]. Preventive measures, early diagnosis, and adequate treatment of infections are potentially decreasing morbidity and mortality.

\section{Epidemiology and MDR infections}

Among hospitalized patients with cirrhosis, infections account for $25-35 \%$ of all admissions and this is 4-5-fold higher rate of infections than in those without cirrhosis $[6,8]$. Bacteria remain the most common pathogens with a prevalence of about $25-46 \%$ in patients hospitalized for acute decompensated cirrhosis [9-11] which then increases the probability of death by approximately 4 -fold, reaching $30 \%$ at 1 month and $63 \%$ at 1 year $[12,13]$. Enterobacteriaceae and non-enterococcal streptococci are the major causes of spontaneous infection in cirrhosis $[4,5]$.

MDR organisms (MDROs) are pathogens which are resistant to at least one agent in $\geq 3$ of the main antibiotic families, including $\beta$-lactams. Examples of MDROs are extended-spectrum $\beta$-lactamase-producing Enterobacteriaceae (ESBL), non-fermentable gram-negative bacilli such as Pseudomonas aeruginosa, Stenotrophomonas maltophilia or Acinetobacter baumannii, methicillin-resistant Staphylococcus aureus (MRSA), and vancomycin-resistant enterococci (VRE) [4]. Nowadays, MDR infections are increasing not only in the hospitals but also in the communities [14•]. The prevalence of MDROs differs among various geographic regions and with higher rates in nosocomial (23-39\%) and healthcare-associated settings (14-41\%) rather than in community-acquired infections (0-16\%) [4, 6, 7]. ESBL-producing Enterobacteriaceae are more predominant isolates in South Europe and Asia, while VRE infections are frequently encountered in the USA and Latin America [14•].

In the recent multicenter intercontinental prospective study "Global study" (2015-2016) of hospitalized patients with cirrhosis across the world $(n=1302)$, the most common infections were SBP $(27 \%)$, UTI $(22 \%)$, and pneumonia $(19 \%)$. Nine hundred fifty-nine microorganisms were isolated (58\% gram-negative, 38\% gram-positive, $4 \%$ fungi). The global prevalence of MDR infection was 34\%. Risk factors for MDROs were an infection in Asia $(\mathrm{OR}=2.79)$ particularly in India, or in South America $(\mathrm{OR}=2.23)$; the use of antibiotics within 3 months before hospitalization $(\mathrm{OR}=1.92)$; the category of infection (nosocomial [OR $=2.65]$, healthcareassociated $[\mathrm{OR}=1.62]$ ); and the site of infection (pneumonia [OR=3.20], UTI $[\mathrm{OR}=2.48]$, skin/soft tissue infection $[\mathrm{OR}=2.92]$ ) [15•]. Further, MDR infections were associated with a lower rate of response to empirical antibiotic treatment ( 40 vs $68 \% ; p<0.001)$, higher incidence of shock ( 27 
vs $15 \% ; p<0.001$ ), new organ failures (42 vs $31 \% ; p=0.001$ ), and higher in-hospital mortality ( 31 vs $21 \% ; p=0.004$ ) than non-MDR infections $[15 \bullet]$.

\section{Pathogenesis of bacterial infections}

Cirrhosis, being an immunomodulatory deficiency state, predisposes such patients to infections through multiple mechanisms (Fig. 1). Bacterial overgrowth and intestinal barrier dysfunction can result in bacterial translocation [18]. Genetic variants in those with cirrhosis have been noted to be associated with an increased risk and severity of infections. Multifactorial pathogenetic mechanisms can cause excessive inflammatory response and thus induce circulatory dysfunction, acute decompensation, and eventual development of acute-on-chronic liver failure (ACLF).

\section{Gut microbiota and bacterial translocation}

Intestinal bacterial overgrowth (IBO), common in patients with cirrhosis, could be a consequence of slow intestinal transit due to decreased bowel motility, low secretion of gastric acid and bile acids, and local intestinal immunological

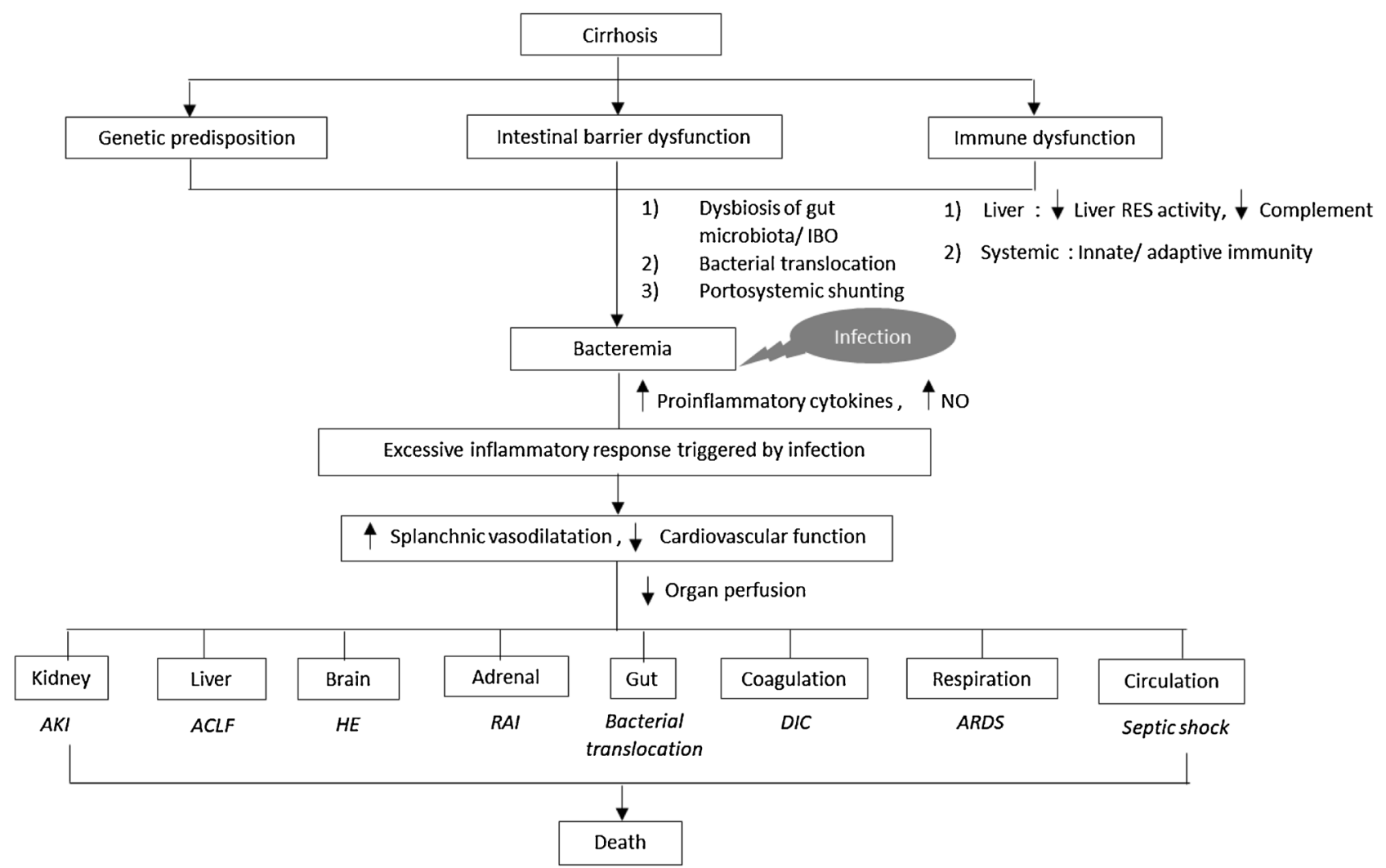

Fig. 1. Pathogenesis of bacterial infections in cirrhosis. (Modified from $[1,4,11,16,17])$ IBO, intestinal bacterial overgrowth; RES, reticuloendothelial system; NO, nitric oxide; AKI, acute kidney injury; ACLF, acute on chronic liver failure; HE, hepatic encephalopathy; RAI, relative adrenal insufficiency; DIC, disseminated intravascular coagulation; ARDS, acute respiratory distress syndrome 
defects [19]. High production of nitric oxide (NO) inducing vasodilatation and portal hypertension may further facilitate bacterial overgrowth [18, 20-22]. IBO can then result in bacterial translocation (BT) and liver inflammation [4]. BT is defined as the migration of microorganisms or bacterial endotoxins from the intestinal lumen to the mesenteric lymph nodes or systemic circulation. The most common bacteria involved in BT are derived from the family of Enterobacteriaceae (E. coli, Klebsiella spp., etc.), Enterococci, and Streptococci spp. These multiple mechanisms can cause a wide range of clinical manifestations, including hemodynamic instability, high proinflammatory cytokine levels, development of severe or recurrent infections, ACLF, hepatic encephalopathy, and hepatorenal syndrome (HRS), and these associated with poor prognosis [18]. Data from 181 patients in The North American Consortium for Study of EndStage Liver Disease (NACSELD) cohort showed that dysbiosis of the intestinal microbiota in hospitalized patients with cirrhosis (particularly changes in Proteobacteria constituents; e.g., Enterobacteriaceae, Campylobacteraceae, and Pasteurellaceae) associates with increased risk of extra-hepatic organ failure, ACLF, and death [23].

\section{Increased intestinal permeability}

In cirrhosis with portal hypertension, the microcirculation in the intestinal mucosa is disturbed with loosening of tight junctions (TJ) between epithelial cells resulting in impairment of mucosal integrity which can facilitate BT [21, 24]. Secreted mediators that limit the direct contact of intestinal bacteria with the epithelial surface and are shown to be deficient in cirrhosis include immunoglobulin A [25], biliary lipids [26], and antimicrobial peptides [4, 27]. This also results in impaired mucus secretion which then facilitates bacterial penetration [18].

\section{Genetic predisposition and immune dysfunction}

Cirrhosis is associated with an immunodeficiency state and the designated "cirrhosis-associated immunodeficiency dysfunction (CAID)" concept includes two entities: (1) immunodeficiency which affects both innate and adaptive immune systems and (2) a state of persistent but inadequate activation of immune system leading to production of proinflammatory cytokines and systemic inflammation. Pathogen-associated molecular patterns (PAMPs) from enteric bacterial organisms and damage-associated molecular patterns (DAMPs), originating from the host tissue upon injury, bring into pattern recognition and activation of immune cells causing systemic inflammation [16]. Further, genetic polymorphisms of immunity pathways may lead to variation in immune responses and infection susceptibilities. Genetic variations coding for pattern recognition receptors (PRR), especially NOD2 and TLR2 variants causing impairment of innate host defense mechanisms, have been associated with SBP susceptibility, and markers of impaired intestinal permeability with higher systemic inflammation in patients with cirrhosis $[4,28]$.

\section{Infection and ACLF}

In those with cirrhosis, ACLF, a unique condition, can evolve following bacterial infections and the presentation is characterized by acute hepatic 
decompensation and multi-organ failure. A large multicenter prospective study of 1343 patients hospitalized from acute decompensation of cirrhosis "CANONIC study" (in the context of EASL-CLIF Consortium) established a definition and categorized grading which defines short-term mortality (ACLF grades $1-3$, mortality $22 \%$ to $77 \%$ ) [29, 30]. In this study, bacterial infection was the most common identifiable precipitating factor for ACLF (33\%), followed by active alcoholism (25\%). Among bacterial infections, SBP and pneumonia were the most frequent sites of infection associated with ACLF. Severity of infection, such as sepsis or septic shock, also correlated with ACLF. The presence or types of precipitating events were not related to mortality, but prognosis depended more on the numbers of organ failures (OFs). In this context, the presence of OFs assessed by the CLIF-SOFA or the CLIF-C OF scores was associated with 28-day and 90-day mortality and it has been suggested that ACLF grading be determined to assess mortality in hospitalized patients with cirrhosis and ACLF. During hospitalization, the majority of patients have been noted to achieve Grade 3 ACLF within the first week. Therefore, the next assessment, since admission, of ACLF grade at days 3-7 with a new scoring system "CLIF-C ACLF score" is suggested as it has a significantly higher predictive accuracy than MELD, MELD-Na, and Child-Pugh-Turcotte score at all main time points after ACLF diagnosis; it has a significantly higher area under the receiver operating curve (AUROC) for prediction of 28-day and 90-day mortality [30].

While again noting a spectrum of infections, a prospective multicenter study in 507 patients with cirrhosis hospitalized with an infection across the USA and Canada (NACSELD consortium database) [31,32] has noted some differences when compared with the EASL-CLIF consortium. The most frequently encountered infections were UTI (28.5\%) and SBP $(22.5 \%)$ while other infections included spontaneous bacteremia (13.2\%), skin/soft tissue (12.2\%), respiratory $(9.9 \%)$, miscellaneous $(9.6 \%)$, and C. difficile (4.1\%). Nosocomial infections, often due to drug-resistant organisms, were found as first infections in $15.8 \%$, and were frequently related to in-hospital procedures, and the use of medications (antibiotics, proton pump inhibitor, or SBP prophylaxis). Most commonly, the infections were due to gram-positive organisms (32.9\%), followed by gram-negative (26.8\%), and fungi (17.6\%); no organisms were

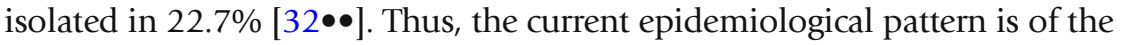
majority being non-SBP infections, domination by gram-positive organisms, and large proportion of nosocomial infections. In addition, second infections developed during hospitalization were encountered in $21.6 \%$ of the patients (UTI 32\%, respiratory infections 25\%, and SBP $12.5 \%$ ), and were also associated with poor survival. Some of the hospitalized patients with bacterial infection developed OFs (1-OF 37\%, 2-OFs 10\%, and 3-OFs 10\%). Poor predictors found to be associated with development of ACLF were nosocomial infections, high baseline MELD, low mean arterial pressure (MAP), and non-SBP infections. Independent predictors of poor 30-day survival were I-ACLF (a simple bedside tool, defined as $\geq 2$ OFs: shock, grade III-IV HE, ventilation, renal replacement therapy), second infections, high admission MELD, high white

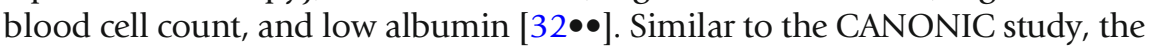
numbers of OFs were found to be an important predictor of overall survival in those with ACLF. In liver transplant-listed patients, in the NACSELD experience, there was a $42 \%$ risk of delisting/death within a 6 -month period following 
an episode of infection due to multiple organ failures, making it likely the main reason for delisting/death among liver transplant-listed patients [33•].

\section{Spontaneous bacterial peritonitis}

\section{Clinical and prevalence}

The prevalence of SBP in outpatients is $1.5-3.5 \%$ and ranges from 10 to $30 \%$ in hospitalized patients with cirrhosis [34]. Fifty percent of cases have evidence of SBP at the time of hospital admission while the rest are acquired during hospitalization [35]. Symptoms include abdominal pain, vomiting, and diarrhea and patients may also have signs of peritonitis or signs of systemic inflammation: fever, leukocytosis, tachycardia, or shock. SBP can be asymptomatic in about a third of the patients [36]. Therefore, diagnostic paracentesis should be performed in all patients with cirrhosis and ascites without delay at hospital admission and/or in patients with gastrointestinal bleeding, shock, signs of systemic inflammation, worsening of liver or renal function, and hepatic encephalopathy $[37 \bullet \bullet]$. Hospital mortality after a first episode of SBP has ranged from 10 to $50 \%$ and 1-year mortality from 31 to $93 \%$ [38].

\section{Diagnosis}

The diagnosis of SBP is defined by ascitic neutrophil count of $\geq 250$ cells $/ \mathrm{mm}^{3}$ with a positive ascitic fluid bacterial culture without the evidence of intraabdominal, surgically treatable source of infection [39]. The methods for estimating neutrophil count include manual count by microscopy, automated count by flow cytometry, or leukocyte esterase reagent strips (LERS), although the last one is not recommended for rapid screening test due to low sensitivity $(45 \%)[37,40]$. While a positive ascitic fluid culture is not essential for the diagnosis of SBP, ascitic and blood culture should still be performed before starting antibiotics as organisms can be isolated in $40-60 \%$ of cases [5, 8]. Levels of ascitic fluid lactoferrin (AFLAC) have been noted to be elevated in SBP. In a prospective study conducted at tertiary centers (218 ascites samples/148 patients) using a cut-off level of $242 \mathrm{ng} / \mathrm{mL}$, the sensitivity and specificity for diagnosis of SBP were $95.5 \%$ and $97 \%$, respectively [41]. Another prospective study from South Korea (182 patients) noted a sensitivity of $95.8 \%$ and specificity of $74.4 \%$ at a cut-off level of $51.4 \mathrm{ng} / \mathrm{mL}$ [42]; however, further validation studies are still needed for it to be recommended in clinical practice. Another newly established in situ hybridization method for detecting the phagocytized bacterial DNA in ascites from SBP patients $(n=51)$ demonstrated a sensitivity of $91 \%$ and specificity of $100 \%$; the results were provided in a day [43].

Secondary peritonitis is another differential diagnosis of peritonitis that should be considered when multi-organisms are encountered on ascites culture, and also when there is growth of anaerobes, fungi, very high ascites neutrophil counts, or in those with inadequate response to therapy. Runyon's criteria are as follows: $\geq 2$ ascitic parameters (ascitic glucose $<50 \mathrm{mg} / \mathrm{dL}$, protein $>10 \mathrm{~g} / \mathrm{L}, \mathrm{LDH}>$ normal serum levels) are helpful in considering this entity and with a sensitivity of $67 \%$ and specificity of $90 \%$. Prompt abdominal CT and early surgical consideration should be pursued $[35,39]$. 
Empirical antibiotic must be started immediately after the diagnosis of SBP and nephrotoxic drugs should be avoided. Choice of empirical antibiotic(s) depends on the type of infection, individual risk factors, and the bacterial epidemiology in a particular global region. For community-acquired SBP, the recommended first-line antibiotic treatment is a third-generation cephalosporins given intravenously for a

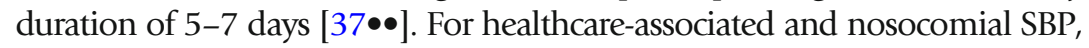
piperacillin/tazobactams are recommended in areas with low prevalence of MDROs. Carbapenem is the antibiotic of choice in regions where there is a high prevalence of ESBL-producing Enterobacteriaceae, and it should be used in combination with glycopeptides or daptomycin or linezolid in areas with high prevalence of gram-positive MDR bacteria (Table 1). Extensive drug resistance (XDR) bacteria, defined by a non-susceptibility to at least one agent in all but two or fewer antimicrobial categories and pan-drug resistance (PDR) bacteria defined by a nonsusceptibility to all agents in all antimicrobial categories [46], may require combination of antibiotics including highly nephrotoxic agents such as vancomycin or aminoglycosides where, if used, plasma levels need to be monitored. Prompt deescalation based on bacterial susceptibility is highly recommended in order to minimize evolution of a resistant strain [37••]. Failure of treatment should be suspected if clinical symptoms worsen or there is inadequate reduction of leukocyte response (less than $25 \%$ of ascitic neutrophil count in $48 \mathrm{~h}$ ).

Intravenous 20\% albumin (1.5 g/kg at diagnosis of SBP followed by $1 \mathrm{~g} / \mathrm{kg}$ on day 3 ), in combination with antibiotics, significantly reduced renal impairment (from 33 to $10 \%$ ) and reduced mortality (from 29 to $10 \%$ ). Albumin infusion is especially effective in patients with total bilirubin of $>4 \mathrm{mg} / \mathrm{dL}$, blood urea nitrogen $>30 \mathrm{mg} / \mathrm{dL}$, or serum creatinine $>1 \mathrm{mg} / \mathrm{dL}[44,47]$.

Prophylaxis of SBP

Three high-risk groups of patients with cirrhosis should be considered for use of prophylaxis to prevent SBP and they include those with acute gastrointestinal bleeding, advanced cirrhosis with low protein ascites (primary prophylaxis), and previous history of SBP (secondary prophylaxis) (Table 2).

Forty-five to $66 \%$ of patients with cirrhosis and with an upper gastrointestinal bleeding developed bacterial infection within 7 days of the bleeding episode [4, 51, 52]. Antibiotics administration can decrease the incidence of infection to $10-20 \%[51,53]$, and has also been associated with a reduction in rebleeding rate, and improved survival [52]. Oral norfloxacin (400 mg/ $12 \mathrm{~h}$ for 7 days) is the gold standard prophylaxis; however, patients with advanced cirrhosis ( $\geq 2$ of the following: ascites, severe malnutrition, encephalopathy, or jaundice) should receive intravenous ceftriaxone $(1 \mathrm{~g} /$ day for 7 days). A randomized controlled trial (RCT) comparing oral norfloxacin and intravenous ceftriaxone in advanced cirrhosis with gastrointestinal hemorrhage showed that the probability of developing possible infections ( $33 \%$ vs $11 \%, p=0.003)$, proven infections $(26 \%$ vs $11 \%, p=$ $0.03)$, and spontaneous bacteremia/SBP $(12 \%$ vs $2 \%, p=0.03)$ is significantly higher in patients receiving oral norfloxacin [53]. 
Table 1. Recommended empirical antibiotic treatment for community-acquired and nosocomial bacterial infections in cirrhosis. (Modified from $[5,14 \bullet, 37 \bullet \bullet, 44]$ )

\begin{tabular}{|c|c|c|c|}
\hline Type of infection & Common bacteria & $\begin{array}{l}\text { Recommended empirical antibiotics } \\
\text { Community-acquired infections }{ }^{\mathrm{a}}\end{array}$ & $\begin{array}{l}\text { Nosocomial }^{b} \text { and } \\
\text { Healthcare-associated } \\
\text { infections }^{c}\end{array}$ \\
\hline $\begin{array}{l}\text { SBP and spontaneous } \\
\text { bacteremia }\end{array}$ & $\begin{array}{l}\text { E. coli, } \\
\text { K. pneumoniae, } \\
\text { S. pneumoniae, } \\
\text { S. viridans }\end{array}$ & $\begin{array}{l}\text { First-line therapy: } \\
\text { IV } 3^{\text {rd }} \text { generation cephalosporins (e.g. } \\
\text { cefotaxime, ceftriaxone) } \\
\text { Other options: } \\
\text { - IV ciprofloxacin or oral ofloxacin (in } \\
\text { uncomplicated SBP)* } \\
\text { - Piperacillin/tazobactam in high rates } \\
\text { of bacterial resistance countries. }\end{array}$ & $\begin{array}{l}\text { Low prevalence of MDR } \\
\text { Piperacillin/tazobactam } \\
\text { High prevalence of MDR } \\
\text { Meropenem+/-glycopeptide\# }\end{array}$ \\
\hline $\begin{array}{l}\text { Urinary tract } \\
\text { infections }\end{array}$ & $\begin{array}{l}\text { E. coli, } \\
\text { K. pneumoniae, } \\
\text { E. faecalis, } \\
\text { E. faecium }\end{array}$ & $\begin{array}{l}\text { Uncomplicated infection:** } \\
\text { Oral ciprofloxacin or co-trimoxazole } \\
\text { Sepsis: } \\
\text { IV } 3^{\text {rd }} \text { generation cephalosporins or } \\
\text { piperacillin/tazobactam }\end{array}$ & $\begin{array}{l}\text { Uncomplicated infection: } \\
\text { Fosfomycin or nitrofurantoin } \\
\text { Sepsis: } \\
\text { Low prevalence of MDR } \\
\text { Piperacillin/tazobactam } \\
\text { High prevalence of MDR } \\
\text { Meropenem+/-glycopeptide\# }\end{array}$ \\
\hline Pneumonia & $\begin{array}{l}\text { S. pneumoniae, } \\
\text { H. influenzae, } \\
\text { K. pneumoniae, } \\
\text { E. coli, } \\
\text { P. aeruginosa, } \\
\text { S. aureus }\end{array}$ & $\begin{array}{l}\text { - Piperacillin/tazobactam or } \\
\text { - Ceftriaxone + macrolide or } \\
\text { - Levofloxacin or } \\
\text { - Moxifloxacin }\end{array}$ & $\begin{array}{l}\text { Low prevalence of MDR } \\
\text { Piperacillin/tazobactam } \\
\text { High prevalence of MDR } \\
\text { Meropenem or ceftazidime }+ \\
\text { levofloxacin }+/- \text { glycopeptide or } \\
\text { linezolid should be added in } \\
\text { patients with risk factors for } \\
\text { MRSA } \S\end{array}$ \\
\hline $\begin{array}{l}\text { Skin and soft tissue } \\
\text { infections }\end{array}$ & $\begin{array}{l}\text { S. aureus, } \\
\text { S. pyogenes, } \\
\text { E. coli, K. } \\
\text { pneumoniae, } \\
P . \text { aeruginosa }\end{array}$ & $\begin{array}{l}\text { - Piperacillin/tazobactam or } \\
-3^{\text {rd }} \text { generation cephalosporins }+ \\
\text { oxacillin }\end{array}$ & $\begin{array}{l}\text { Meropenem or ceftazidime }+ \\
\text { oxacillin or glycopeptide\# }\end{array}$ \\
\hline \multicolumn{4}{|c|}{ 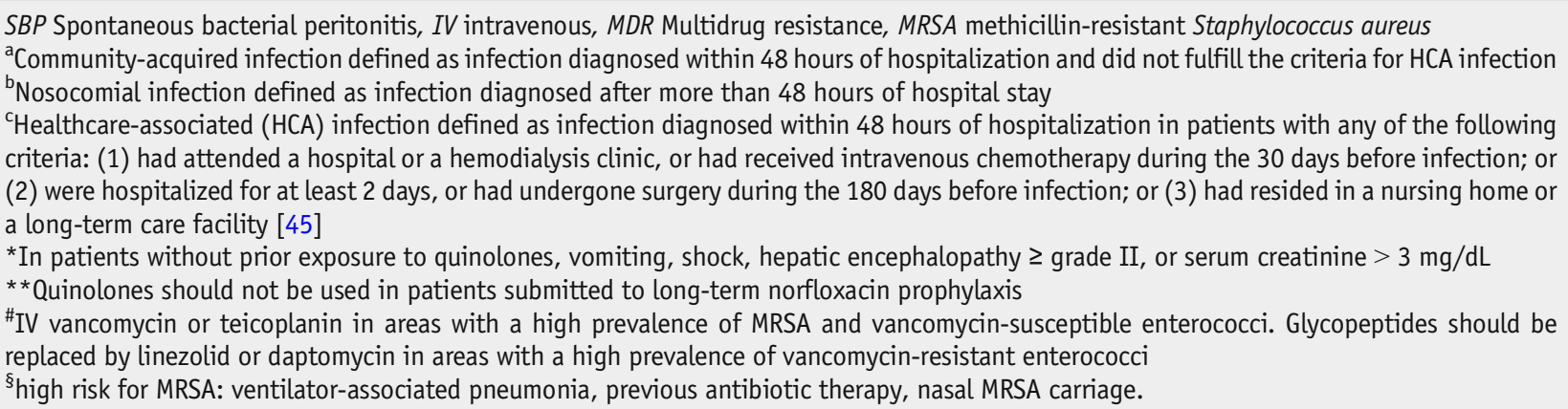 } \\
\hline
\end{tabular}


Primary prophylaxis with norfloxacin $400 \mathrm{mg} /$ day is recommended in patients with advanced cirrhosis (Child-Pugh score $\geq 9$ and serum bilirubin $\geq 3 \mathrm{mg} / \mathrm{dL})$ and low ascitic protein $(<1.5 \mathrm{~g} / \mathrm{dL})$ with either impaired renal function (serum creatinine $\geq 1.2 \mathrm{mg} / \mathrm{dL}$ or blood urea nitrogen $\geq 25 \mathrm{mg} /$ $\mathrm{dL}$ ) or hyponatremia (serum sodium $\leq 130 \mathrm{mEq} / \mathrm{L}$ ). An RCT evaluated norfloxacin prophylaxis versus no intervention in high-risk patients of developing SBP and HRS, and noted that norfloxacin demonstrated improvement in the 3-month (94\% vs $62 \% ; p=0.003$ ) and 1-year survival $(60 \%$ vs $48 \% ; p=0.05)$, and significantly reduced the 1 -year probability of developing SBP ( $7 \%$ vs $61 \% ; p<0.001)$ and HRS $(28 \%$ vs $41 \% ; p=0.02)$ [54]. In addition, ciprofloxacin $500 \mathrm{mg} /$ day for 12 months has also been shown to improve 1 -year survival ( $86 \%$ vs $66 \% ; p<0.04$ ) [55].

Secondary prophylaxis

Secondary prophylaxis with norfloxacin $400 \mathrm{mg}$ /day is advised in patients who had experienced an episode of SBP. In an RCT study performed in patients who had a previous episode of SBP, the long-term use of norfloxacin $400 \mathrm{mg} /$ day reduced the 1-year probability of SBP recurrence from 68 to $20 \%[35,56]$. However, there is no clear recommendation on the duration of the prophylactic antibiotics, but ideally they should continue until liver transplantation (LT) or death. For those who are on rifaximin as a preventive intervention for recurrent hepatic encephalopathy, there is no recommendation on either primary or secondary prophylaxis of SBP. Prospective studies are necessary to evaluate the benefits and adverse

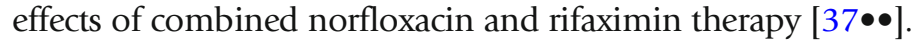

A downside of the long-term use of antibiotic prophylaxis is the emergence of resistant bacteria as noted in a prospective study which reported a higher prevalence of quinolone-resistant organisms in patients with cirrhosis receiving long-term norfloxacin prophylaxis ( $85 \%$ vs $47 \%$ receiving placebo; $p=0.0001$ ) [6]. As of now, non-antibiotic prophylaxis (e.g., pre/probiotics, fecal microbiota transplantation) are undergoing investigation [14•].

\section{Infections other than SBP}

\section{Urinary tract infection}

UTI is a common bacterial infection and is the second most frequent infection after SBP and it accounts for $12-29 \%$ of infectious complications in decompensated cirrhosis [57]. Most of the isolated organisms (70-80\%) are gramnegative bacteria such as E. coli and K. pneumonia. UTI can be asymptomatic and asymptomatic bacteriuria can also be encountered at high frequency. This could possibly be related to the frequently found residual urinary volume and vesical dysfunction in those with cirrhosis [58, 59].

Empirical antibiotics for community-acquired UTI in those with cirrhosis include intravenous third-generation cephalosporins or piperacillin/ tazobactam if there is associated sepsis, and oral quinolones or trimethoprim- 
sulfamethoxazole in uncomplicated UTI. Quinolones are not recommended as first-line treatment in those already on long-term norfloxacin prophylaxis [5] (Table 1). Several studies have found that nosocomial-acquired UTIs are associated with the presence of a urinary catheter around $63-75 \%$ [60, 61], other risks such as performance of urological procedure during admission are also associated with catheter-associated urinary tract infections (CAUTIs) (OR 1.17; 95\% CI 1.11-1.22; $p<0.001$ ) [62]. Common microorganisms isolated from CAUTIs are Enterococcus spp., E. coli, and P. aeruginosa which can be multidrugresistant strains [63-65]. Additionally, in patients with cirrhosis, urinary catheterization during an admission was found associated more with MDR bacterial infections than non-MDR (32\% vs $10 \% ; p=0.0001)$ [6]. This brings to the concern of catheter withdrawal as soon as possible for patients with cirrhosis in order to prevent CAUTIs.

\section{Pneumonia}

In the hospitalized patients with cirrhosis, pneumonia carries the highest risk of mortality than other infections (HR $=2.95(2.05-4.25)$ ) [66]. Development of pneumonia is associated with a more severe form of community-acquired pneumonia (CAP), and may be associated with bacteremia, multi-lobar involvement, impaired consciousness, renal failure, and septic shock (overall mortality $7.4 \%$ vs $14.4 \% ; p<0.024$ ) [67]. The risk of hospital-acquired pneumonia (HAP) is increased in the setting of hepatic encephalopathy and tracheal intubations. The most common pathogen for CAP pneumonia in those with cirrhosis is still Streptococcus pneumoniae, and similar to patients without cirrhosis. The predominant pathogens for HAP pneumonia are gram-negative bacilli and staphylococci, and which is also associated with high mortality [66, 68]. Empirical antibiotic use in cirrhosis with HAP pneumonia consists of an intravenous anti-pseudomonal cephalosporin or carbapenem, plus fluoroquinolone, and/or glycopeptide in high-risk patients for MRSA organisms (Table 1).

The most common causative organisms for cellulitis are gram-positive bacteria (group A streptococci and Staphylococcus aureus) but gram-negative organisms (include E. coli, Klebsiella spp., P. aeruginosa, Aeromonas spp., Vibrio spp.) are also frequently reported in those with cirrhosis [69]. Necrotizing fasciitis caused by gram-negative bacteria tends to have concurrent bacteremia and initially present with septic shock [70]. High awareness for this manifestation is necessary for early surgical intervention in order to decrease morbidity and mortality. Empirical treatment is highly effective in community-acquired skin and soft tissue infection (SSTI), and in only one third with nosocomial SSTI [71]. Broad-spectrum antibiotics such as third-generation cephalosporins in combination with oxacillin, or piperacillin-tazobactam, should be promptly initiated. (Table 1).

Fungal infections can be another cause of treatment failure in patients with cirrhosis, especially in patients who are hospitalized in intensive care units [72] or with alcoholic hepatitis [73]. A study in hospitalized patients with cirrhosis and with a culture-positive infection during 2008-2014 $(n=185)$ noted an approximate $10 \%$ rate of fungal infections $(8(4.3 \%)$ combined bacterial and fungal 
infection, and $11(6 \%)$ fungal infection only). In the fungal infection group, spontaneous fungal peritonitis (SFP) with positive ascitic fluid culture was in $58 \%(n=11 / 19)$ and fungemia (positive blood culture) without SFP was in $42 \%$ $(n=8 / 19)$. Most fungal infections were due to Candida spp., with C. albicans and nearly all Candida species were sensitive to amphotericin B, fluconazole, and voriconazole. Nine (47.4\%) of the fungal infections were nosocomial infections and seven (36.8\%) were healthcare-associated [74]. Mortality rates at 1 month and 6 months were $57.9 \%$ and $89.5 \%$, respectively, which were significantly higher than those with bacterial infections. Fungal infections may occur with or without bacterial infections, but often are in those with impaired renal function (creatinine $1.6 \mathrm{vs} 1.1 \mathrm{mg} / \mathrm{dL} ; p=0.034)$ and in healthcare-associated/nosocomial settings $(100 \%$ vs $28.3 \% ; p=0.007)$. Ascitic fluid characteristics cannot distinguish SFP from SBP. Therefore, hemoculture, ascitic fluid culture for fungi, and empiric use of anti-fungal agents may be considered in those patients with cirrhosis and with nosocomial infections who are not responding to empirical antibiotics therapy [74]. In the NACSELD cohort ( $n=2743), 134$ patients (12.7\% of infected patients) had evidence of fungal infections, all of which were nosocomial. The rate of fungal infections did not correlate with the etiology of cirrhosis. A multi-variable analysis noted that diabetes, acute kidney injury, ICU admission, and admission bacterial infection were associated with fungal infections $(A U C=0.82)$. Further, fungal infections were associated with ACLF and poor 30-day survival [75].

In patients with alcoholic hepatitis, the STOPAH trial demonstrated a higher rate of infections in prednisolone-treated patients than in the non-prednisolone group ( $13 \%$ vs $7 \% ; p=0.002)$ [76]. A recent meta-analysis of 1062 patients with severe alcoholic hepatitis (528 steroids treated) found no difference in infection rates between those treated and untreated with corticosteroids. However, fungal infections were higher among those who received corticosteroids (8/528 vs $1 / 534 ; p=0.02$ ) [77]. Invasive aspergillosis is another frequent complication seen in those with severe alcoholic hepatitis and carries high mortality; thus, systemic and periodic screening for opportunistic pathogens in such patients is recommended [78].

\section{Vaccination}

Immunization against influenza, pneumococcus, and hepatitis A and B is recommended in patients with chronic liver disease. Inactivated or killed-type vaccinations are more preferable than live attenuated vaccinations in patients with cirrhosis [79]. Yearly inactivated influenza vaccination should be provided to every chronic liver disease patient due to its safety and effectiveness in protection.

Pneumonia accounts for 15-20\% of infections in cirrhosis which also carries the highest 30- and 90-day mortality rate among other sources of infections [66]. The higher incidence and greater severity of pneumonia from Streptococcus pneumoniae in those with cirrhosis argues for the administration of pneumococcal vaccine to all adult ( $>18$ years old) patients with cirrhosis and with booster dose after 65 years old (Table 2).

Superimposed infection with hepatitis A or B in patients with chronic liver disease or cirrhosis is associated with increased morbidity and mortality [80, 81]. As immunogenicity to vaccinations has correlated inversely with the degree of hepatic decompensation [82], early immunization against hepatitis A and $\mathrm{B}$ prior to the 
Table 2. Antibiotics prophylaxis and vaccinations in patients with cirrhosis. (Modified from $[4,48 \bullet \bullet, 49,50]$ )

\author{
Prophylactic antibiotics \\ Indications \\ Gastrointestinal bleeding \\ Primary prophylaxis of SBP: \\ Patients with low protein ascites $(<1.5 \mathrm{~g} / \mathrm{dL}$ ) with advanced \\ cirrhosis (Child-Pugh score $\geq 9$ and serum bilirubin $\geq 3 \mathrm{mg} / \mathrm{dL}$ ) \\ and/or renal dysfunction (serum creatinine $\geq 1.2 \mathrm{mg} / \mathrm{dL}$ or BUN $\geq$ \\ $25 \mathrm{mg} / \mathrm{dL}$ or serum sodium $\leq 130 \mathrm{mEq} / \mathrm{L}$ ) \\ Secondary prophylaxis of SBP
}

\section{Vaccinations}

Inactivated influenza

Pneumococcal vaccine (2 types)

1) 13-valent pneumococcal conjugate vaccine (PCV13)

2) 23-valent pneumococcal polysaccharide vaccine (PPSV23)

Hepatitis A

Hepatitis B

Other vaccines (e.g. Td, Tdap, Zoster, HPV, MMR, varicella)

\section{Recommendations}

-Oral norfloxacin ( $400 \mathrm{mg} / 12 \mathrm{~h}$ for 7 days)

-Patients with advanced cirrhosis ( $\geq 2$ of the followings: ascites, malnutrition, encephalopathy or jaundice): IV ceftriaxone (1 $\mathrm{g} /$ day for 7 days)

-Oral norfloxacin $400 \mathrm{mg} /$ day or ciprofloxacin $500 \mathrm{mg} /$ day until liver transplantation or death

-Oral norfloxacin $400 \mathrm{mg} /$ day until liver transplantation, death, resolution of ascites, or improvement into a compensated status

Recommended annually in all chronic liver disease patients Recommended in all chronic liver disease patients

- Administer 1 dose of PPSV23 at 19-64 years.

- Administer 1 dose of PCV13 at $\geq 65$ years old. This dose should be given at least 1 year after PPSV23.

- Administer 1 final dose of PPSV23 at $\geq 65$ years old. This dose should be given at least 1 year after PCV13 and at least 5 years after the most recent dose of PPSV23.

Recommended for all chronic liver disease patients without serologic marker of HAV exposure (anti-HAV total)

- Administer 1 dose at 0 and 6-12 months (Havrix) Or 1 dose at 0 and $6-18$ months (Vaqta)

Recommended for all chronic liver disease patients without serological markers of HBV (negative HBsAg, negative anti-HBs)

In adult $\geq 20$ years old:

- Administer 1 dose of $10 \mu \mathrm{g} / \mathrm{mL}$ (Recombivax HB) at 0, 1, 6 months

Or 1 dose of $20 \mu \mathrm{g} / \mathrm{mL}$ (Engerix-B) at 0, 1, 6 months Patients who cannot achieve seroconversion especially with more advanced cirrhosis may benefit from a high-dose or double-dose $(40 \mu \mathrm{g})$ strategy.

- 1 dose of $40 \mu \mathrm{g} / \mathrm{mL}$ (Recombivax HB) at 0, 1 and 6 months or

- 2 doses of $20 \mu \mathrm{g} / \mathrm{mL}$ (Engerix-B) at 0, 1, 2 and 6 months

In chronic liver disease : recommended as same as general adult populations.

In advanced cirrhosis : live attenuated vaccinations (e.g. Zoster, MMR, varicella) cannot yet be comfortably recommended.

IV intravenous, SBP spontaneous bacterial peritonitis, BUN blood urea nitrogen, HBV hepatitis B virus, Td tetanus-diphtheria, Tdap tetanusdiphtheria-pertussis, HPV human papilloma virus, MMR measles/mumps/rubella 
stage of hepatic decompensation is the optimal strategy. Hepatitis A vaccination in patients with decompensated cirrhosis had low seroconversion rates of about 49$66 \%[79,83,84]$, and thus this group of patients may benefit from post-

vaccination serologic testing to evaluate response. Similarly, hepatitis B vaccination has been noted to be safe and with high seroconversion rates in patients with mild to moderate chronic liver disease, but has reduced efficacy in advanced chronic liver disease and in those who underwent liver transplantation [85-87]. Weight and age of the patients are also factors associated with the response rate. Thus, patients with chronic liver disease should be vaccinated before the onset of advanced fibrosis or cirrhosis if possible by conventional hepatitis B vaccination series. Although patients with cirrhosis may benefit from a high-dose or double-dose (40 $\mu \mathrm{g})$ strategy (68\% response rate) [88] than standard doses (16-20\% response rate) [89-91], it remains controversial. As such, a double-dose vaccination is only recommended in other immunocompromised status (e.g., HIV, hemodialysis, on chemotherapy or hematopoietic stem-cell transplant) [50]. However, from our perspective, patients with cirrhosis who do not achieve seroconversion (Anti-HBs $>10 \mathrm{mIU} / \mathrm{mL}$ ) following a vaccination course may benefit from a second double-dose $(40 \mu \mathrm{g})$ regimen (Table 2).

Disappointingly, vaccination rates in patients with cirrhosis remain suboptimal. A retrospective study of the trends in vaccination between 2004 and 2013 ( $n=$ $17,990)$ found only $19.8 \%, 7.7 \%$, and $11.0 \%$ of patients receiving a pneumococ$\mathrm{cal}$, hepatitis A, and hepatitis B vaccine, respectively, in the same or the following year of cirrhosis diagnosis [92]. Adherence by patients and physicians to vaccination guidelines are of paramount importance in order to reduce morbidity and mortality from vaccine-preventable diseases in patients with cirrhosis.

\section{Compliance with Ethical Standards}

\section{Conflict of Interest}

Sirina Ekpanyapong, MD, declares that she has no conflict of interest.

K. Rajender Reddy, MD, declares that he has no conflict of interest for this work.

Human and Animal Rights and Informed Consent

This article does not contain any studies with human or animal subjects performed by any of the authors.

\section{References and Recommended Reading}

1. Bonnel AR, Bunchorntavakul C, Reddy KR. Immune dysfunction and infections in patients with cirrhosis. Clinical Gastroenterol Hepatol. 2011;9(9):727-38. https://doi.org/10.1016/j.cgh.2011.02.031.

2. Mookerjee RP, Stadlbauer V, Lidder S, Wright GA, Hodges SJ, Davies NA, et al. Neutrophil dysfunction in alcoholic hepatitis superimposed on cirrhosis is reversible and predicts the outcome. Hepatology. 2007;46(3):831-40. https://doi.org/10.1002/hep.21737.
3.

Wasmuth HE, Kunz D, Yagmur E, Timmer-Stranghoner A, Vidacek D, Siewert E, et al. Patients with acute on chronic liver failure display "sepsis-like" immune paralysis. J Hepatol. 2005;42(2):195-201. https://doi. org/10.1016/j.jhep.2004.10.019.

4. Jalan R, Fernandez J, Wiest R, Schnabl B, Moreau R, Angeli $\mathrm{P}$, et al. Bacterial infections in cirrhosis: a position statement based on the EASL Special Conference 2013. J Hepatol. 2014;60(6):1310-24. https://doi.org/ 10.1016/j.jhep.2014.01.024. 
5. Fernandez J, Gustot T. Management of bacterial infections in cirrhosis. J Hepatol. 2012;56(Suppl 1):S1-12. https://doi.org/10.1016/S0168-8278(12)60002-6.

6. Fernandez J, Acevedo J, Castro M, Garcia O, de Lope $\mathrm{CR}$, Roca D, et al. Prevalence and risk factors of infections by multiresistant bacteria in cirrhosis: a prospective study. Hepatology. 2012;55(5):1551-61. https:// doi.org/10.1002/hep.25532.

7. Merli M, Lucidi C, Giannelli V, Giusto M, Riggio O, Falcone $\mathrm{M}$, et al. Cirrhotic patients are at risk for health care-associated bacterial infections. Clin Gastroenterol Hepatol. 2010;8(11):979-85. https://doi.org/10. 1016/j.cgh.2010.06.024.

8. Fernandez J, Navasa M, Gomez J, Colmenero J, Vila J, Arroyo V, et al. Bacterial infections in cirrhosis: epidemiological changes with invasive procedures and norfloxacin prophylaxis. Hepatology.

2002;35(1):140-8. https://doi.org/10.1053/jhep. 2002.30082

9. Moreau R, Jalan R, Gines P, Pavesi M, Angeli P, Cordoba J, et al. Acute-on-chronic liver failure is a distinct syndrome that develops in patients with acute decompensation of cirrhosis. Gastroenterology. 2013;144(7):1426-37,37.e1-9. https://doi.org/10. 1053/j.gastro.2013.02.042.

10. Fasolato S, Angeli P, Dallagnese L, Maresio G, Zola E, Mazza E, et al. Renal failure and bacterial infections in patients with cirrhosis: epidemiology and clinical features. Hepatology. 2007;45(1):223-9. https://doi.org/ 10.1002/hep.21443.

11. Piano S, Brocca A, Mareso S, Angeli P. Infections complicating cirrhosis. Liver Int. 2018;38(Suppl 1):12633. https://doi.org/10.1111/liv.13645.

12. Foreman MG, Mannino DM, Moss M. Cirrhosis as a risk factor for sepsis and death: analysis of the National Hospital Discharge Survey. Chest. 2003;124(3):1016-20.

13. Arvaniti V, D'Amico G, Fede G, Manousou P, Tsochatzis E, Pleguezuelo $\mathrm{M}$, et al. Infections in patients with cirrhosis increase mortality four-fold and should be used in determining prognosis. Gastroenterology. 2010;139(4):1246-56,56.e1-5. https://doi. org/10.1053/j.gastro.2010.06.019.

14. Fernandez J, Bert F, Nicolas-Chanoine MH. The challenges of multi-drug-resistance in hepatology. J Hepatol. 2016;65(5):1043-54. https://doi.org/10. 1016/j.jhep.2016.08.006

A brief review of treatment strategies and global health crisis of antimicrobial resistance in cirrhosis.

15. Piano S, Singh V, Caraceni P, Maiwall R, Alessandria C, Fernandez J, et al. Epidemiology, predictors and outcomes of multi drug resistant (MDR) bacterial infections in patients with cirrhosis across the world. Final results of the "Global study". Digestive and Liver Disease. 2018;50(1, supplement):2-3. https://doi.org/10. $1016 /$ j.dld.2018.01.007

A multicenter study of global prevalence and epidemiology of MDR bacterial infections in cirrhosis.

16. Albillos A, Lario M, Alvarez-Mon M. Cirrhosisassociated immune dysfunction: distinctive features and clinical relevance. J Hepatol. 2014;61(6):1385-96. https://doi.org/10.1016/j.jhep.2014.08.010.

17. Bunchorntavakul C, Chavalitdhamrong D. Bacterial infections other than spontaneous bacterial peritonitis in cirrhosis. World J Hepatol. 2012;4(5):158-68. https://doi.org/10.4254/wjh.v4.i5.158.

18. Alexopoulou A, Agiasotelli D, Vasilieva LE, Dourakis SP. Bacterial translocation markers in liver cirrhosis. Ann Gastroenterol. 2017;30(5):486-97. https://doi. org/10.20524/aog.2017.0178.

19. Bellot P, Garcia-Pagan JC, Frances R, Abraldes JG, Navasa M, Perez-Mateo M, et al. Bacterial DNA translocation is associated with systemic circulatory abnormalities and intrahepatic endothelial dysfunction in patients with cirrhosis. Hepatology. 2010;52(6):204452. https://doi.org/10.1002/hep.23918.

20. Sadik R, Abrahamsson H, Bjornsson E, Gunnarsdottir A, Stotzer PO. Etiology of portal hypertension may influence gastrointestinal transit. Scand J Gastroenterol. 2003;38(10):1039-44.

21. Reiberger T, Ferlitsch A, Payer BA, Mandorfer M, Heinisch BB, Hayden $\mathrm{H}$, et al. Non-selective betablocker therapy decreases intestinal permeability and serum levels of LBP and IL-6 in patients with cirrhosis. J Hepatol. 2013;58(5):911-21. https://doi. org/10.1016/j.jhep.2012.12.011.

22. Guarner C, Soriano G, Tomas A, Bulbena O, Novella MT, Balanzo J, et al. Increased serum nitrite and nitrate levels in patients with cirrhosis: relationship to endotoxemia. Hepatology. 1993;18(5):1139-43.

23. Bajaj JS, Vargas HE, Reddy KR, Lai JC, O'Leary JG, Tandon $\mathrm{P}$, et al. Association between intestinal microbiota collected at hospital admission and outcomes of patients with cirrhosis. Clin Gastroenterol Hepatol. 2018;17:756-765.e3. https://doi.org/10.1016/j.cgh. 2018.07.022.

24. Assimakopoulos SF, Tsamandas AC, Tsiaoussis GI, Karatza E, Triantos C, Vagianos CE, et al. Altered intestinal tight junctions' expression in patients with liver cirrhosis: a pathogenetic mechanism of intestinal hyperpermeability. Eur J Clin Investig. 2012;42(4):439-46. https://doi.org/10.1111/j.13652362.2011.02609.x.

25. Saitoh O, Sugi K, Lojima K, Matsumoto H, Nakagawa $\mathrm{K}$, Kayazawa M, et al. Increased prevalence of intestinal inflammation in patients with liver cirrhosis. World J Gastroenterol. 1999;5(5):391-6.

26. Lorenzo-Zuniga V, Bartoli R, Planas R, Hofmann AF, Vinado B, Hagey LR, et al. Oral bile acids reduce bacterial overgrowth, bacterial translocation, and endotoxemia in cirrhotic rats. Hepatology. 2003;37(3):551-7. https://doi.org/10.1053/jhep. 2003.50116.

27. Teltschik Z, Wiest R, Beisner J, Nuding S, Hofmann C, Schoelmerich J, et al. Intestinal bacterial translocation in rats with cirrhosis is related to compromised Paneth cell antimicrobial host defense. Hepatology. 2012;55(4):1154-63. https://doi.org/10.1002/hep. 24789. 
28. Bruns T, Zimmermann HW, Stallmach A. Risk factors and outcome of bacterial infections in cirrhosis. World J Gastroenterol. 2014;20(10):2542-54. https://doi. org/10.3748/wjg.v20.i10.2542.

29. Arroyo V, Jalan R. Acute-on-chronic liver failure: definition, diagnosis, and clinical characteristics. Semin Liver Dis. 2016;36(2):109-16. https://doi.org/10. 1055/s-0036-1583202.

30. Hernaez R, Sola E, Moreau R, Gines P. Acute-onchronic liver failure: an update. Gut. 2017;66(3):54153. https://doi.org/10.1136/gutjnl-2016-312670.

31. O'Leary JG, Reddy KR, Garcia-Tsao G, Biggins SW, Wong F, Fallon MB, et al. NACSELD acute-on-chronic liver failure (NACSELD-ACLF) score predicts 30-day survival in hospitalized patients with cirrhosis. Hepatology. 2018;67(6):2367-74. https://doi.org/10. 1002/hep.29773.

32.• Bajaj JS, O'Leary JG, Reddy KR, Wong F, Biggins SW, Patton $\mathrm{H}$, et al. Survival in infection-related acute-onchronic liver failure is defined by extrahepatic organ failures. Hepatology. 2014;60(1):250-6. https://doi. org/10.1002/hep. 27077

The study using NACSELD database on prevalence and survival of infection-related ACLF in hospitalized cirrhotic patients.

33.• Reddy KR, O'Leary JG, Kamath PS, Fallon MB, Biggins SW, Wong F, et al. High risk of delisting or death in liver transplant candidates following infections: results from the North American Consortium for the Study of End-Stage Liver Disease. Liver Transpl.

2015;21(7):881-8. https://doi.org/10.1002/lt.24139

The study using NACSELD database on prognosis of liver transplant candidates following infections.

34. Evans LT, Kim WR, Poterucha JJ, Kamath PS. Spontaneous bacterial peritonitis in asymptomatic outpatients with cirrhotic ascites. Hepatology. 2003;37(4):897-901. https://doi.org/10.1053/jhep.2003.50119.

35. Rimola A, Garcia-Tsao G, Navasa M, Piddock LJ, Planas $\mathrm{R}$, Bernard B, et al. Diagnosis, treatment and prophylaxis of spontaneous bacterial peritonitis: a consensus document. International Ascites Club. J Hepatol. 2000;32(1):142-53.

36. Chinnock B, Afarian H, Minnigan H, Butler J, Hendey GW. Physician clinical impression does not rule out spontaneous bacterial peritonitis in patients undergoing emergency department paracentesis. Ann Emerg Med. 2008;52(3):268-73. https://doi.org/10.1016/j. annemergmed.2008.02.016.

37.• EASL. Clinical Practice Guidelines for the management of patients with decompensated cirrhosis. J Hepatol. 2018;69(2):406-60. https://doi.org/10.1016/j.jhep. 2018.03.024

An updated EASL guideline and recommendations 2018 for bacterial infections in cirrhosis including both SBP and nonSBP infections.

38. Wiest R, Krag A, Gerbes A. Spontaneous bacterial peritonitis: recent guidelines and beyond. Gut. 2012;61(2):297-310. https://doi.org/10.1136/gutjnl2011-300779.
39. Runyon BA. Management of adult patients with ascites due to cirrhosis: an update. Hepatology. 2009;49(6):2087-107. https://doi.org/10.1002/hep. 22853.

40. Nousbaum JB, Cadranel JF, Nahon P, Khac EN, Moreau $\mathrm{R}$, Thevenot T, et al. Diagnostic accuracy of the Multistix 8 SG reagent strip in diagnosis of spontaneous bacterial peritonitis. Hepatology. 2007;45(5):1275-81. https:// doi.org/10.1002/hep. 21588.

41. Parsi MA, Saadeh SN, Zein NN, Davis GL, Lopez R, Boone J, et al. Ascitic fluid lactoferrin for diagnosis of spontaneous bacterial peritonitis. Gastroenterology. 2008;135(3):803-7. https://doi.org/10.1053/j.gastro. 2008.05.045.

42. Lee SS, Min HJ, Choi JY, Cho HC, Kim JJ, Lee JM, et al. Usefulness of ascitic fluid lactoferrin levels in patients with liver cirrhosis. BMC Gastroenterol. 2016;16(1):132. https://doi.org/10.1186/s12876-016-0546-9.

43. Enomoto $\mathrm{H}$, Inoue $\mathrm{S}$, Matsuhisa A, Aizawa N, Imanishi $\mathrm{H}$, Saito $\mathrm{M}$, et al. Development of a new in situ hybridization method for the detection of global bacterial DNA to provide early evidence of a bacterial infection in spontaneous bacterial peritonitis. J Hepatol. 2012;56(1):85-94. https://doi.org/10.1016/j.jhep. 2011.06.025.

44. Runyon BA. Introduction to the revised American Association for the Study of Liver Diseases Practice Guideline management of adult patients with ascites due to cirrhosis 2012. Hepatology. 2013;57(4):16513. https://doi.org/10.1002/hep.26359.

45. Venditti M, Falcone M, Corrao S, Licata G, Serra P. Outcomes of patients hospitalized with community-acquired, health care-associated, and hospitalacquired pneumonia. Ann Intern Med. 2009;150(1):19-26.

46. Magiorakos AP, Srinivasan A, Carey RB, Carmeli Y, Falagas ME, Giske CG, et al. Multidrug-resistant, extensively drug-resistant and pandrug-resistant bacteria: an international expert proposal for interim standard definitions for acquired resistance. Clin Microbiol Infect. 2012;18(3):268-81. https://doi.org/10.1111/j. 1469-0691.2011.03570.x.

47. Sort P, Navasa M, Arroyo V, Aldeguer X, Planas R, Ruizdel-Arbol $L$, et al. Effect of intravenous albumin on renal impairment and mortality in patients with cirrhosis and spontaneous bacterial peritonitis. $\mathrm{N}$ Engl J Med. 1999;341(6):403-9. https://doi.org/10.1056/ NEJM199908053410603.

48.• Bunchorntavakul C, Chamroonkul N, Chavalitdhamrong D. Bacterial infections in cirrhosis: a critical review and practical guidance. World J Hepatol. 2016;8(6):307-21. https://doi.org/10.4254/wjh.v8.i6.307

A detailed review of bacterial infections in cirrhosis.

49. Kobayashi M, Bennett NM, Gierke R, Almendares O, Moore MR, Whitney CG, et al. Intervals between PCV13 and PPSV23 vaccines: recommendations of the Advisory Committee on Immunization Practices (ACIP). MMWR Morb Mortal Weekly Rep. 2015;64(34):944-7. https:// doi.org/10.15585/mmwr.mm6434a4. 
50. Mast EE, Weinbaum CM, Fiore AE, Alter MJ, Bell BP, Finelli $\mathrm{L}$, et al. A comprehensive immunization strategy to eliminate transmission of hepatitis B virus infection in the United States: recommendations of the Advisory Committee on Immunization Practices (ACIP) Part II: immunization of adults. MMWR Recomm Rep. 2006;55(Rr-16):1-33quiz CE1-4.

51. Blaise M, Pateron D, Trinchet JC, Levacher S, Beaugrand M, Pourriat JL. Systemic antibiotic therapy prevents bacterial infection in cirrhotic patients with gastrointestinal hemorrhage. Hepatology. 1994;20(1 Pt 1):34-8.

52. Chavez-Tapia NC, Barrientos-Gutierrez T, Tellez-Avila F, Soares-Weiser K, Mendez-Sanchez N, Gluud C, et al. Meta-analysis: antibiotic prophylaxis for cirrhotic patients with upper gastrointestinal bleeding - an updated Cochrane review. Aliment Pharmacol Ther. 2011;34(5):509-18. https://doi.org/10.1111/j.13652036.2011.04746.x.

53. Fernandez J, Ruiz del Arbol L, Gomez C, Durandez R, Serradilla R, Guarner C, et al. Norfloxacin vs ceftriaxone in the prophylaxis of infections in patients with advanced cirrhosis and hemorrhage. Gastroenterology. 2006;131(4):1049-56;quiz 1285. https://doi.org/10. 1053/j.gastro.2006.07.010.

54. Fernandez J, Navasa M, Planas R, Montoliu S, Monfort D, Soriano G, et al. Primary prophylaxis of spontaneous bacterial peritonitis delays hepatorenal syndrome and improves survival in cirrhosis. Gastroenterology. 2007;133(3):818-24. https://doi.org/10.1053/j. gastro.2007.06.065.

55. Terg R, Fassio E, Guevara M, Cartier M, Longo C, Lucero $\mathrm{R}$, et al. Ciprofloxacin in primary prophylaxis of spontaneous bacterial peritonitis: a randomized, placebocontrolled study. J Hepatol. 2008;48(5):774-9. https://doi.org/10.1016/j.jhep.2008.01.024.

56. Gines P, Rimola A, Planas R, Vargas V, Marco F, Almela M, et al. Norfloxacin prevents spontaneous bacterial peritonitis recurrence in cirrhosis: results of a double-blind, placebo-controlled trial. Hepatology. 1990;12(4 Pt 1):716-24.

57. Navasa M, Rimola A, Rodes J. Bacterial infections in liver disease. Semin Liver Dis. 1997;17(4):323-33. https://doi.org/10.1055/s-2007-1007209.

58. Burroughs AK, Rosenstein IJ, Epstein O, HamiltonMiller JM, Brumfitt W, Sherlock S. Bacteriuria and primary biliary cirrhosis. Gut. 1984;25(2):133-7.

59. Cruz Rde C, Tanajura D, Almeida D, Cruz M, Parana R. Urinary tract infection in non-hospitalized patients with cirrhosis and no symptoms of urinary tract infection: a case series study. Braz J Infect Dis.

2006;10(6):380-3.

60. Bjerklund Johansen TE, Cek M, Naber K, Stratchounski L, Svendsen MV, Tenke P. Prevalence of hospitalacquired urinary tract infections in urology departments. Eur Urol. 2007;51(4):1100-11;discussion 12. https://doi.org/10.1016/j.eururo.2006.08.012.

61. Bouza E, San Juan R, Munoz P, Voss A, Kluytmans J. A European perspective on nosocomial urinary tract infections II. Report on incidence, clinical characteristics and outcome (ESGNI-004 study). European Study Group on Nosocomial Infection. Clin Microbiol Infect. 2001;7(10):532-42.

62. Jimenez-Alcaide E, Medina-Polo J, Garcia-Gonzalez L, Arrebola-Pajares A, Guerrero-Ramos F, Perez-Cadavid $S$, et al. Healthcare-associated urinary tract infections in patients with a urinary catheter: risk factors, microbiological characteristics and patterns of antibiotic resistance. Arch Esp Urol. 2015;68(6):541-50.

63. Tenke P, Kovacs B, Bjerklund Johansen TE, Matsumoto T, Tambyah PA, Naber KG. European and Asian guidelines on management and prevention of catheterassociated urinary tract infections. Int J Antimicrob Agents. 2008;31(Suppl 1):S68-78. https://doi.org/10. 1016/j.ijantimicag.2007.07.033.

64. Sievert DM, Ricks P, Edwards JR, Schneider A, Patel J, Srinivasan A, et al. Antimicrobial-resistant pathogens associated with healthcare-associated infections: summary of data reported to the National Healthcare Safety Network at the Centers for Disease Control and Prevention, 2009-2010. Infect Control Hosp Epidemiol. 2013;34(1):1-14. https://doi.org/10.1086/668770.

65. Chitnis AS, Edwards JR, Ricks PM, Sievert DM, Fridkin SK, Gould CV. Device-associated infection rates, device utilization, and antimicrobial resistance in long-term acute care hospitals reporting to the National Healthcare Safety Network, 2010. Infect Control Hosp Epidemiol. 2012;33(10):993-1000. https://doi.org/ $10.1086 / 667745$.

66. Hung TH, Tseng CW, Hsieh YH, Tseng KC, Tsai CC, Tsai CC. High mortality of pneumonia in cirrhotic patients with ascites. BMC Gastroenterol. 2013;13:25. https://doi.org/10.1186/1471-230X-13-25.

67. Viasus D, Garcia-Vidal C, Castellote J, Adamuz J, Verdaguer R, Dorca J, et al. Community-acquired pneumonia in patients with liver cirrhosis: clinical features, outcomes, and usefulness of severity scores. Medicine. 2011;90(2):110-8. https://doi.org/10.1097/ MD.0b013e318210504c.

68. Cheruvattath R, Balan V. Infections in patients with end-stage liver disease. J Clin Gastroenterol. 2007;41(4):403-11. https://doi.org/10.1097/01.mcg. 0000248018.08515.f9.

69. Hamza RE, Villyoth MP, Peter G, Joseph D, Govindaraju C, Tank DC, et al. Risk factors of cellulitis in cirrhosis and antibiotic prophylaxis in preventing recurrence. Ann Gastroenterol. 2014;27(4):374-9.

70. Lee CC, Chi CH, Lee NY, Lee HC, Chen CL, Chen PL, et al. Necrotizing fasciitis in patients with liver cirrhosis: predominance of monomicrobial Gram-negative bacillary infections. Diagn Microbiol Infect Dis. 2008;62(2):219-25. https://doi.org/10.1016/j. diagmicrobio.2008.05.016.

71. Acevedo JG, Fernandez J, Castro M, Garcia O, de Lope CR, Navasa M, et al. 6 current efficacy of recommended empirical antibiotic therapy in patients with cirrhosis and bacterial infection. J Hepatol. 2009;50:S5. https:// doi.org/10.1016/S0168-8278(09)60008-8. 
72. Lahmer T, Messer M, Mayr U, Saugel B, Noe S, Schultheiss C, et al. Fungal "colonisation" is associated with increased mortality in medical intensive care unit patients with liver cirrhosis. Mycopathologia.

2015;179(1-2):63-71. https://doi.org/10.1007/ s11046-014-9825-6.

73. Lahmer T, Messer M, Schwerdtfeger C, Rasch S, Lee M, Saugel B, et al. Invasive mycosis in medical intensive care unit patients with severe alcoholic hepatitis. Mycopathologia. 2014;177(3-4):193-7. https://doi. org/10.1007/s11046-014-9740-x.

74. Alexopoulou A, Vasilieva L, Agiasotelli D, Dourakis SP. Fungal infections in patients with cirrhosis. J Hepatol. 2015;63(4):1043-5. https://doi.org/10.1016/j.jhep. 2015.05 .032$.

75. Bajaj JS, Rajender Reddy K, Tandon P, Wong F, Kamath PS, Biggins SW, et al. Prediction of fungal infection development and their impact on survival using the NACSELD cohort. Am J Gastroenterol. 2018;113(4):55663. https://doi.org/10.1038/ajg.2017.471.

76. Thursz MR, Richardson P, Allison M, Austin A, Bowers $\mathrm{M}$, Day CP, et al. Prednisolone or pentoxifylline for alcoholic hepatitis. N Engl J Med. 2015;372(17):161928. https://doi.org/10.1056/NEJMoa1412278.

77. Hmoud BS, Patel K, Bataller R, Singal AK. Corticosteroids and occurrence of and mortality from infections in severe alcoholic hepatitis: a meta-analysis of randomized trials. Liver Int. 2016;36(5):721-8. https:// doi.org/10.1111/liv.12939.

78. Gustot T, Maillart E, Bocci M, Surin R, Trepo E, Degre $\mathrm{D}$, et al. Invasive aspergillosis in patients with severe alcoholic hepatitis. J Hepatol. 2014;60(2):267-74. https://doi.org/10.1016/j.jhep.2013.09.011.

79. Leise MD, Talwalkar JA. Immunizations in chronic liver disease: what should be done and what is the evidence. Curr Gastroenterol Rep. 2013;15(1):300. https://doi. org/10.1007/s11894-012-0300-6.

80. Almasio PL, Amoroso P. HAV infection in chronic liver disease: a rationale for vaccination. Vaccine. 2003;21(19-20):2238-41.

81. Keeffe EB. Acute hepatitis A and B in patients with chronic liver disease: prevention through vaccination. Am J Med. 2005;118(Suppl 10A):21s-7s. https://doi. org/10.1016/j.amjmed.2005.07.013.

82. Smallwood GA, Coloura CT, Martinez E, Stieber AC, Heffron TG. Can patients awaiting liver transplantation elicit an immune response to the hepatitis A vaccine? Transplant Proc. 2002;34(8):3289-90.
83. Arguedas MR, Johnson A, Eloubeidi MA, Fallon MB. Immunogenicity of hepatitis A vaccination in decompensated cirrhotic patients. Hepatology.

2001;34(1):28-31. https://doi.org/10.1053/jhep. 2001.25883 .

84. Dumot JA, Barnes DS, Younossi Z, Gordon SM, Avery RK, Domen RE, et al. Immunogenicity of hepatitis A vaccine in decompensated liver disease. Am J Gastroenterol. 1999;94(6):1601-4. https://doi.org/10. 1111/j.1572-0241.1999.01150.x.

85. Roni DA, Pathapati RM, Kumar AS, Nihal L, Sridhar K, Tumkur RS. Safety and efficacy of hepatitis B vaccination in cirrhosis of liver. Adv Virol. 2013;2013:196704-5. https://doi.org/10.1155/2013/196704.

86. Keeffe EB, Krause DS. Hepatitis B vaccination of patients with chronic liver disease. Liver Transpl Surg. 1998;4(5):437-9.

87. Chlabicz S, Grzeszczuk A. Hepatitis B virus vaccine for patients with hepatitis $C$ virus infection. Infection. 2000;28(6):341-5.

88. Bonazzi PR, Bacchella T, Freitas AC, Osaki KT, Lopes $\mathrm{MH}$, Freire MP, et al. Double-dose hepatitis B vaccination in cirrhotic patients on a liver transplant waiting list. Braz J Infect Dis. 2008;12(4):306-9.

89. Horlander JC, Boyle N, Manam R, Schenk M, Herring S, Kwo PY, et al. Vaccination against hepatitis B in patients with chronic liver disease awaiting liver transplantation. Am J Med Sci. 1999;318(5):304-7.

90. Carey W, Pimentel R, Westveer MK, Vogt D, Broughan T. Failure of hepatitis B immunization in liver transplant recipients: results of a prospective trial. Am J Gastroenterol. 1990;85(12):1590-2.

91. Mendenhall C, Roselle GA, Lybecker LA, Marshall LE, Grossman CJ, Myre SA, et al. Hepatitis B vaccination. Response of alcoholic with and without liver injury. Dig Dis Sci. 1988;33(3):263-9.

92. Waghray A, Waghray N, Khallafi H, Menon KV. Vaccinating adult patients with cirrhosis: trends over a decade in the United States. Gastroenterol Res Pract. 2016;2016:5795712-7. https://doi.org/10.1155/ $2016 / 5795712$.

\section{Publisher's Note}

Springer Nature remains neutral with regard to jurisdictional claims in published maps and institutional affiliations. 